\title{
POST COLONIAL ECOFEMINISM: A CRITICAL STUDY
}

\author{
DR. SILIMA NANDA
}

Additional Director, IGNOU, BBSR, India

\begin{abstract}
The article highlights the concept of Ecofeminism as a bonding of women with nature where both are victims of destruction and the study aims to end this exploitation in the contemporary context. According to the views of some Ecofeminist there exist a relation not only from the sociological point of view but also from the religious, cultural, literary and theological perspectives. Ecofeminism as a movement was born by the convergence of ecology and feminism that aimed at reconstructing society based not on exploitation of nature/ women rather to promote a balance between the two by restoring the oppressive forces of the society. Ecofeminism as a movement started from the west in the late 1970s and such movements have always vindicated the importance of the sustainability of nature. Examples are the Chipko movement in India, the Green Belt movement in Kenya and the anti-militarist movements of Europe and U.S.A.. My article is a study on the aspects of ecofeminism as analyzed in the major works of Indian English fiction writers.
\end{abstract}

KEYWORDS: Ecofeminism, Woman, Oppression \& Environment

Received: Jul 27, 2021; Accepted: Aug 17, 2021; Published: Sep 14, 2021; Paper Id.: IJELDEC202111

\section{INTRODUCTION}

Ecofeminism is a synonym of the term ecological feminism that projects a semblance between the exploitation of women as a species and Nature that have been exploited for ages, at the behest of the masculine dominion. Ecofeminism is the other name for ecological feminism, a branch of feminism that examines the interrelation between women and nature, by drawing a parallel between the exploitation of both against the context of patriarchy. According to Vandana Shiva (1988) the ecofeminist, the scientific development and the industrial revolution of Europe in the $17^{\text {th }}$ century had resulted in the destruction of women and nature. The need for capital growth and economic development has resulted in the denigration of nature from Prakriti into a machine, producing resources which have resulted in the current day ecological crisis. The ecofeminists draw a parallel between gender and nature and are of the view that the subjugation of women, as well as the depletion of nature, is due to the detrimental effects resulted from Patriarchy and the ownership of Capital by the male folk. Any strategy to benefit one of these should be thoughtfully implemented because the relationship of Gender and Nature are so intricately linked that to benefit one might have an adverse impact on the other. The equality offered to women should not be at the cost of the destruction of the natural world. It is time that the structure of patriarchy which has remained in prevalence since the last many decades needs to be reinterpreted and deconstructed because to resolve one must take into account its impact on the other so that women's equality should not be achieved at the expense of worsening the environment, and neither should environmental improvements be gained at the expense of women. The field of Ecofeminism is the other name for Anthropocentrism or Patriarchal dominion that manifests in sexual subordination and the exploitation of women. The definition of society is built on a dualistic process that places patriarchy on a higher platform, otherwise called the seat of power or the Centre whereas women and nature are at 
the margins, divested of any authority or ownership. Both of them have a subjugated existence, relentlessly exploited by the male world to serve their interests. The balance of gender has been a lopsided one from time immemorial. To cite the instance of Sita in Ramayana or Draupadi in Mahabharata, despite their spirit of endurance and self respect they were humiliated which provoked them to take the cudgels of resistance. Perhaps this was the way the feminist temper had its birth.

The French feminist, Francoise d'Eaubonne in her book Le Féminisme ou la Mort (Feminism or Death) first introduced the word 'ecofeminism' which stated patriarchy as the principal cause for the exploitation of women as well as the wreckage of nature. According to Francoise d'Eaubonne, Ecofeminism is a movement aimed "to remake the planet around a totally new model She believed that for humanity to survive or be restored, it is necessary to balance the two poles(male and female) because if the male domination persists then the society would definitely crush and die..(D'Eaubonne, Francoise (1974): The term though introduced by Francoise eventually gained popularity in the protests against the exploitation of nature that resulted in recurring natural disasters.

Later this concept took a systematic form by Ynestra King in 1976 and culminated as a movement in the first ecofeminist conference on "Women and Life on Earth: Ecofeminism in the 80s" in 1980 at Amherst Massachusetts, U. S. The essence of ecofeminism highlights the benign impact of Mother Earth on the one hand and on the other propels fight for the protection of the rights of gender and nature. According to the eco-feminists one needs to realize the interdependence of the life processes, the basis of which rests on empathy, compassion, motherhood, ability to care and create.

According to Birkeland, Ecofeminism is a "value system, a social movement, and a practice... (which) offers a political analysis that explores the links between androcentrism and environmental destruction. It is an "awareness" that begins with the realization that the exploitation of nature is intimately linked to Western Man's attitude toward women and tribal cultures..." (1993, p.18). The ecofeminist Sturgeon is of the view that "Ecofeminism is a movement that establishes a connection between environmentalism and feminism; more precisely, it articulates the theory that the ideologies that authorize injustices based on gender, race and class are related to the ideologies that sanction the exploitation and degradation of the environment." [Sturgeon - 23]. The first strand of ecofeminism which is still relevant today is Cultural feminism that refers to woman-nature connections as “liberating and empowering expressions of women's capabilities to care for nature" [Warren, Web Source]. The role of a mother is parallel to the image of mother-earth that stands as symbols of love, fertility, nourishment and life process.

If we consider Ecofeminism in India we observe that the essence of the Gandhian viewpoints has been influential in shaping Indian feminism in many ways because he did not consider women as helpless creatures deserving charitable concern, rather he saw them as active and self-conscious agents of social change. This prompted many women to come to the forefront of the Indian Freedom struggle. Bankim Chandra Chatterjee's patriotic song 'Vande Mataram' rendered a further emphasis to this ideal preached by Gandhi. While the Gandhian concept helped to attract many women to the forefront of the freedom movement, the British programmes of social reformation including women's education, Sati demolition (1829), Hindu Widow Remarriage Act (1856) and the Age of Consent Acts of 1860, 1891 were some reformative movements from which sprung the modern Indian feminism in the socio-political scene of India. 


\section{ECOFEMINIST LITERATURE}

Coming to Eco feminist literature it portrays the historical exploitation and simultaneously delineates the dialectical relationship of women and nature - where both are seen as victims 'The use of metaphors of women as 'nurturing' - like the earth, and of the earth as female ... are regressive rather than liberating women"[Biehl 1991 PP-17-19]. Viewed historically it is observed that from the beginning of civilization, women's bonding with nature has helped in the sustenance of life on earth. However gradually with the growth of the capitalist economy, the ownership of all sorts of physical resources and economic assets were in the hands of the male folks while women as the dependent sex were relegated to the domestic spheres. They were looked upon as symbols of nurture and care. Commenting on ecofeminism Bina Agarwal the critic mentions that women's potentialities were frozen instead of given chance to expand. Socially women's relation to the environment has been a variable one. They have been victims of environmental degradation and simultaneously agents for the preservation and regeneration of the environment. The best instance is the "Chipko Movement' of the 1970s; that took place in the Garhwal Himalayas, where women raised their voices and manifested their concern for protecting the environment by hugging trees to prevent activities like deforestation, lumbering, mining that subvert forest regeneration. The 'Chipko' Movement is thus an iconic example of ecofeminism in India. In a similar manner, in the present milieu, the other women who have raised their voices for the sake of protecting the environment are Medha Patkar, Mahasweta Devi, Arundhati Roy, C. K. Janu and many tribal women over forest-based conflicts in the tribal areas of Bihar, Odisha, M.P, Maharashtra and A. P. These movements made the women realize the symbiotic connection between nature and human sustenance. Thus ecofeminism is a green movement which urges women to see their similarities with nature and to protect it for the coming generation. These champions of eco-feminism resorted to Gandhian techniques of protests and there were no violent means used by them. Vandana Shiva, a prominent advocate of feminism in India, is of the view that the women of the third world women are not mere victims of the development process but also have the drive and power for bringing change. Shiva sees these women as close to nature and considers them as Indian symbols of 'Shakti' and 'Prakriti'.

\section{INTERSECTIONS AND REFLECTIONS}

Apart from women as social activists, who championed ecofeminism, there are also post-colonial Indian women authors who voiced their concerns for environmental and other linked social issues. Through their writings, the Indian women writers unraveled new ways of interacting with the environment. Rightly Bina Agrawal the ecofeminist critic contends that "woman's position in society is such that they are the most affected by environmental decline and consequently most interested in resisting it" ( Braidotti et al, 173). Arundhati Roy is a very prominent activist- writer and the author of the novel - 'The God of Small Things' who clearly portrays through a variety of narrative techniques. i.e. characterization, ironic juxtaposition and symbols, the subjugation and suppression of women. In Kamala Markandaya's novel, 'Nectar in a sieve' the postcolonial predicament in which the women struggle to survive, has been delineated very meticulously. In this, Markandya depicts the impact of industrialization and communicates the uncertain political climate that forms the setting of the novel. The importance of land as an organic entity looms large in the lives of the women in the novel. Through the depiction of the life of Rukmini, Kamala Markandya reveals the economic hardships the women are faced within India. Indira Ganesan observes that "by giving voice to Rukmani, Markandaya gives us a woman who affects us deeply through not only the burden of rural life but also the burden of being a woman. (Ganesan IV). The concept of ecofeminism is manifested in Rukmani's early stage as a child-bride wife when she develops a strong bonding with the land, expressing 
that "when the sun shines on you and the fields are green and beautiful to the eye ... you have a good store of grain laid away for hard times, a roof over you and a sweet stirring in your body, what more can a woman ask for"? (NIS 33).

When Rukmani says that Nature to her is the source of her well-being. Her excitement is beautifully revealed as she takes care of her garden and plants the pumpkin seeds. "With each tender seedling that unfurled it small green leaf to my eager gaze, my excitement would rise and mount, winged, wondrous (NIS-49). In both novels of Anita Desai: 'Cry, the Peacock' as well as 'Fire on the Mountain' the novelist expresses her concern for the position of middle class Indian Women who are aligned with animals into inferior and stereotyped positions. 'Fire on the Mountain' depicts the physical violence inflicted on the women as well as the animals who are treated at par. Like Maya in 'Cry the Peacock', Raka too gets distressed at the violence meted out to animals around her. Raka cries 'leave her, leave her '(FOTM, 78) as Ramlal hurls stones towards the baby langurs.

In Sohila Abdulalil's, 'The Mad woman of Togare' Abdulali portrays the predicament of young girls like Sangeeta and Lata, who marry at a young age and are neglected by their in-laws. They turn into child-bearing machines. Abdulali voices the ecofeminists' firm faith in nurturing the health of mankind along with the natural environment. We find that the identity of the female protagonists both in Markandaya's "Nectar in a Sieve" and Abdulali's 'The Madwoman of Togare' are resolved by their return to nature.

The close association of women with the animal world is subtly portrayed in the novels of Amitav Ghosh's 'The Hungry Tide' and Nilanjana Roy's 'The Wildings'. It is seen that the homes for Maya, Nanda and Raka are not safe places for them as violence ruptures the walls of their domestic world where the women are confined. In the novels of Gita Mehta and Arundhati Roy, Nature in the form of river becomes an important backdrop as "sutra" accrued with cleansing properties. The motif of water runs throughout the novel and is beautifully interweaved with the theme of desire and sexuality. Rima symbolizing desire, sex and unorthodox convention parallels the flow of water. The destructive aspects of the Meenachal River are an affirmation of the immortal river described in Mehta's novel. Flowing through the heart of Ayemenem, it becomes the site of major happenings in the novel, forming the border between the "touchable" and the "untouchable" worlds. The readers can place Roy's voice heralding to preserve the sanctity and integrity of rivers and their associated biotic world.

Besides the above mentioned novelists, there are fiction writers who honestly explore the women's plight in India and the world. Here references can be made to the works of Kamala Das, Sashi Deshpande, Jhumpa Lahari, Amitav Ghosh who reflect the elements of nature and their relationship with human beings. They focus on the connection of postcolonial and environmental issues, its impact on gender and family relations. Thus their writings though appears very specific and personal also voice concerns of the impact of "mutual interpenetration" (Mukherjee 19) of post-colonial globalization. These Indian novelists have a unique way of associating the environment by connecting women with the larger ecological issues like racism, displacement, and gender exploitation. They highlight that the platform of exploitation between nature and women is similar and has an undisputable linkage. The latent potential of the marginalized women in society also contributes to sustainable development.

\section{Role of Contemporary Social Activists}

Other than the ecofeminist writers who beautifully build a vision of the intersection of the human world and the environment, there are also contemporary women social activists who have contributed immensely to the protection of the 
environment. They are C. K. Janu, a tribal woman fighting for an environmental cause; occupying the Muthanga forests in North Kerala, Arundhati Roy protesting for the Narmada Bachao (Gujarat) to nuclear testing in India. Tulasi Munda hailing from Odisha fighting for the rights of the impoverished adivasis of the state. She was awarded the Padamashri in 2001 for her contribution to the field of 'social work'. Kamala Pujari of a tribal dominated village in Odisha has successfully preserved hundreds of indigenous paddies and has fought for the preservation of the endangered environment. In recent times, the young environmental activist, Greta Thunberg has very aggressively and emotionally expressed in the United Nations, openly reprimanding the world leaders for destroying her dreams and her childhood with their total apathy on the serious problem of climate change. Thunberg caustically criticized the members of the U.N. for being the benevolent donor for the so called economic growth whereas they have no concern about the ecosystems which are facing a collapse causing human misery and resulting in the depletion of ecological resources. To quote her she mentioned that the "popular idea" of cutting emissions by 50 percent in 10 years only yields a 50 percent chance of keeping the earth's warming trend below the 1.5 degree Celsius threshold, which could set off "catastrophic chain reactions beyond human control" if breached. She boldly declared that. "You are failing us but young people are starting to understand your betrayal," Thunberg commented: "The eyes of all future generations are upon you and if you choose to fail us, I say we will never forgive you".(https://www.nbcnews.com/news/world/teen-climate-activist-greta-thunberg-delivers-scathingspeech-u-n-n1057621).

\section{Glimpses from Films}

If we analyze the film world, with a special reference to Bollywood, the mention of 'Mother India' becomes significant as it beautifully depicted the universality of the mother figure as a symbol of life and land. Also in films like Phoolan Devi, Begum Jaan, women have been projected raising their voices against injustice for preserving their self-dignity and position in society. Thus through ecofeminism one comes to understand the relationship of man and nature and their interdependence. In order to have a balanced human community of gender equality men should learn to adapt and change their outlook, in respect of their relationship with women visa-a-vis nature as any excess or overexploitation will lead to devastating the ecological balance.

\section{REFERENCES}

1. Abdulali, Sohaila. The Madwoman of Jogare. New Delhi: HarperCollins Publishers, 1998.

2. Agarwal, Bina The Gender and Environment Debate: Lessons from India. Feminist Studies 18 (1): 1992.

3. Banerjee N., Indian Women in a Changing Industrial Scenario, Oxford University Press, Delhi 1991

4. Zidan, Ashraf Ibrahim. "Postcolonial feminism in Margaret Atwood's fiction." International Journal of Linguistics and Literature 2.3 (2013): 11-20.

5. Birkeland J., Ecofeminism: Linking Theory and Practice, in G. Gaard (ed.), Ecofeminism: Women, Animals and Nature, Temple University Press, Philadelphia 1993

6. $\quad$ Biehl J. Rethinking Ecofeminist Politics, South End Press, Boston 1991.

7. D'Eaubonne, Francoise : Le Temps de L'Ecoféminisme, in Le Féminisme ou la Mort, Pierre Horay, Paris, pp.215-252, Ruth Hottell tr. as The Time for Ecofeminism, in Key Concepts in Critical Theory, Ecology, Carolyn Merchant (ed.), Rawat Publications, Jaipur and New Delhi, India, 1996, p. 176s

8. Desai, Anita. Cry, The Peacock. New Delhi: Orient, 1980. Print. 

Fire on the Mountain. London: Vintage Books, 1977.

10. Ganesan, Indira. "Introduction to Nectar in a Sieve”. Nectar in a Sieve. New York: Signet Classics, 2002

11. King, Ynestra. "The Ecology of Feminism and the Feminism of Ecology", Healing the Wounds: The Promise of Ecofeminism. Ed. Judith Plant. Philadelphia; Santa Cruz: New Society Publishers, 1989

12. Sharma, Garima. "A Critical Study of the Biology Curriculum at Senior Secondary Stage With Respect to Life Skills Education and the HIV/AIDS Education." IASET: International Journal of Library \& Educational Science (IASET: IJLES) 2.3 (2016): 110.

13. Markandaya, Kamala. Nectar in a Sieve. New York: Signet Classic, 1982. Print.

14. Mehta, Gita. A River Sutra. London: Vintage, 1994.

15. Rao, Raja. Kanthapura. New Delhi: Oxford University Press, 2006.Print.

16. Roy, Arundhati. The God of Small Things. London: Flamingo, 1997.

17. Shiva, Vandana. Staying Alive: Women, Ecology and Development. New Delhi: Kali for Women, 1989.

18. Sturgeon, Noel. Ecofeminist Natures: Race, Gender, Feminist Theory and Political Action. New York; London: Routledge, 1997.

19. Warren, Karen J. "Feminist Theory: Ecofeminist and Cultural Feminist" .International Encyclopedia of the Social and Behavioural Sciences. Available at <www.sciencedirect.com> Accessed at 13 October, 2019. 